\title{
Design and Synthesis of Quipazine Based Re-Complexes for the Development of Potential SPECT Imaging Agents with ${ }^{99 m}$ Tc for 5-HT Transporter
}

\author{
Mi-Young In, Dae Yoon Chi, ${ }^{\ddagger}$ Sun-Ju Choi, Kyung-Bae Park, ${ }^{\ddagger}$ and Cheon-Gỵu Cho ${ }^{\star}$ \\ Department of ('hemisty. Hanyang Liversin, Seoul 133-791, Korea \\ ${ }^{\dagger}$ Department of (hemisty, Inha lniversity, Inchon 402-751, Lorea \\ Radioisotope \& Radiation Application Team, HANARO, KALRI, Daejeon 305-301, Lorea \\ Received JuH 18,2002
}

\begin{abstract}
6-Nitroquiparine has higher binding allinity Jor SГRT than other selective serotonin reuptake inhibitors. We have prepared 6-nitroquipazine based thenium compleses which would lead to the development of potential SPГCCT imaging agents with ${ }^{(x)}$ Te lor 5-HT transporter.
\end{abstract}

Key Words : Serotonin, Radiotracer. SH'EC'I, lechnetium, Rhenium

\section{Introduction}

Scrolonin 1ransporter (SERT), responsible for the reuplake of serotonin (5-HT). plays a key role in the regulation of

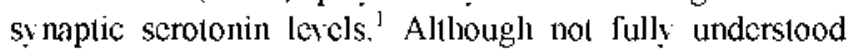
yet. 5 -HT is thought to be implicated in many mental disorders including depression, anxicy. schizophrenia. cating disorders and obsessive compulsive disorder." Serolonin transporter sites are the primary targets for common antidepressant drugs such as fluoxeline. sertraline. and paroxetinc. In wive inaging of SERT in living luman bcings have becn pursucd either by PET (positron emission tomograplyy) or by SPECT (single photon emission compuled lomograplyy) in order to understand the neurological mechanisms underlying those psychiatric disorders. ${ }^{3}$

Except for a few successful cases. for cxample. $\left.{ }^{11} \mathrm{C}\right](+)$ McN5652' for PET and [ $^{23}$ IJDAM for SPECT, the development of such radiotracers has mel with only limited success mostly due to their low signal to noise ratios and poor seleclivity. For a rouline clinical usc. SPECT imaging is preferred to PET icclinique for its operational comenience and practicality. Both ${ }^{123} \mathrm{I}$ and ${ }^{x / 3} \mathrm{Te}$ are the common radionuclides suilable for SPECT imaging. Altachunent of ${ }^{12} \mathrm{I}$ to a target substrate is nomally made througl the displacement reaction of lis with trialkyltin group on the aryl moicty of the target molcculc. Introduction of ${ }^{M_{u n}} \mathrm{Tc}$ is rather difficult. in symthelic point of vicw. since it requires a multidentate ligand. connected covalenty to the substrate for stable Tccomplexes. Furlhermore. 1he conncetion of such chelating groups to a substrate incritably causes the increase of molecular weight and possible confonmational clanges. which may lead to the reduction of its binding affinity in several orders. The advantages of ${ }^{12} \mathrm{I}$ are. however oversluadowed by its lesser accessibility. requiring a cyclotron for its gencration. It is thus mucl desirable to develop radiotracers based on more readily available ${ }^{\text {thu }} \mathrm{Tc}$. despite the aforementioncd drawbacks.

In this present work. we wish to report synthesis of sereral 6-nitroquipazine ligands as well as Re- and Tc-complexes as novel polential radiotracers for the imaging of SERT. We chose 6-nitroquipazine for its high binding aflinity with SERT. ${ }^{*}$ In fact. Matlis et al, reported sy ntheses of 5-[ ${ }^{1-3}[]-6-$ nitro quiparine and $5-\left[{ }^{6} \mathrm{Br}\right]-6$-nilroquiparine derivatives for SPECT and PET imagings. Rhenium is a congener of lechnctium in group VIIa of the periodic table that is commonly used as a model for synthetic viability and spectroscopic characteri/ations.

\section{Results and Discussion}

Adopting the belter synthetic procedures developed by one of us. ${ }^{\text {lo }}$ we prepared the key 6-nitroquipazine derivatic 10 with lydroxypropyl landlc. starting from 3.4-dilydro2(1H)-quinolinone 1. Deprotonation with 2.0 cquiy of LDA at C3 position. Followed by quenching with 3-bromopropanol TMS-cther (2) provided the sily] ether 3 in $85 \%$ yicld. Desilylated alcohol was nitrated to give the dilyydroquinolinone 5 in overall yicld of $40 \%$. The acelylated product 6 was treated with phosphorus oxychloride and DDQ 10 give the 2-chloroquipazine 7 in $80 \%$ isolated yicld. Displacement reaction with l-piperazinccasboxaldehyde (8) provided 9. which was deacetylated to the alcohol 10. The resulting alcohol was reacled with $\mathrm{MsCl}$ in $\mathrm{CH}_{2} \mathrm{Cl}_{2}$ to furnish the mesylate 11 in $52 \%$ y icld (Scheme 1).

The mesylate 11. however. did not undergo substitution reaction with the tetradentate ligand 12 . Instead. it underwent intramolecular displacement reaction. Icading to the fonnation of the cyclic ammonium species 13 as shown in Scheme 2. which might be the reason for the low yicld in the mesylation siep.

Change of the mesylate group on 11 to the bromide or tosylate gave no improvements. Use of the $\mathrm{OH}$ group as a nucleoplite would be a reasonable aliemative. The alcohol 10 was treated witl bromoacelyl bromide. before the coupling with 12 to provide the 6-nitroquiparine derivative $1+$ bearing the ligand for the chelation of Tc or Re.

The ligand 15 was subjected $10{ }^{(\%)} \mathrm{Tc}$ loading conditions to produce the ${ }^{3 / n} \mathrm{~T}$ Tc-complex 16 . which was isolated in pure form by reversed phase HPLC. Howerer. we noticed partial decomposition of the starting ligand and the product ${ }^{2 / \pi n} \mathrm{Tc}-$ 
<smiles>O=C1CCc2ccccc2N1</smiles>

2) $\mathrm{Br}\left(\mathrm{CH}_{2}\right)_{3} \mathrm{OTBS}(2)$

$85 \%$<smiles>CCCOCCCC1Cc2ccccc2NC1=O</smiles><smiles>CC(C)(C)[Mg]</smiles><smiles>O=C1Nc2ccccc2CC1CCCO</smiles><smiles>O=S(=O)(O[Na])O[Na]</smiles><smiles>[O]</smiles><smiles>Cc1cc2cc(N)ccc2nc1OC1CCCCC1</smiles><smiles>CC(=O)OCCCc1cc2cc([N+](=O)[O-])ccc2nc1N1CCN(C=O)CC1</smiles><smiles>CC(=O)OCCCC1Cc2cc([N+](=O)[O-])ccc2NC1=O</smiles><smiles>O=C1CCCCCCCCC1</smiles><smiles>O=C1Nc2ccc([N+](=O)[O-])cc2CC1CCCO</smiles>

$6 \mathrm{H}$

$98 \%$

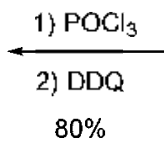

$0 \%$

$$
5 \mathrm{H}
$$

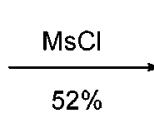<smiles>COCCCc1cc2cc([N+](=O)[O-])ccc2nc1N1CCN(C=O)CC1</smiles>

Scheme 1. Preparalion of the piperazine substituled 6-nitroquipazine derivative.<smiles>COCCCc1cc2cc([N+](=O)[O-])ccc2nc1N1CCN(C=O)CC1</smiles>

11

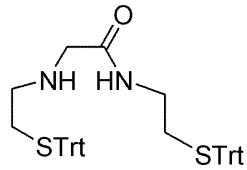

12

\section{$\underset{\mathrm{RT} \text { to reflux }}{\stackrel{\mathrm{K}_{2} \mathrm{CO}_{3} / \mathrm{CH}_{2} \mathrm{Cl}_{2}}{\longrightarrow}}$}<smiles>O=CN1CC[N+]2(CCCc3cc4cc([N+](=O)[O-])ccc4nc32)CC1</smiles>

Scheme 2. Result of the attempled displacement reaclion of the mesylate $\mathbf{1} \mathbf{1}$ with $\mathbf{1 2}$.<smiles>[R]OCCCc1cc2cc([N+](=O)[O-])ccc2nc1N1CCN(C=O)CC1</smiles>

12, $\mathrm{K}_{2} \mathrm{CO}_{3} / \mathrm{CH}_{3} \mathrm{CN}(79 \%)$<smiles>CCC[Si]CCNC(=O)CN(CC[Sn])CC(=O)OCCCc1cc2cc([N+](=O)[O-])ccc2nc1N1CCN(C=O)CC1</smiles>

Scheme 3. Preparalion of the 6-mitrocluiparine- $N_{2} \mathrm{~S}_{2}$ ligand system 15.

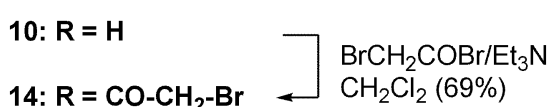

$\mathrm{BrCH}_{2} \mathrm{COBr} / \mathrm{Et}$
$\mathrm{CH}_{2} \mathrm{Cl}_{2}(69 \%)$

15

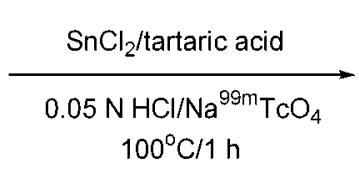

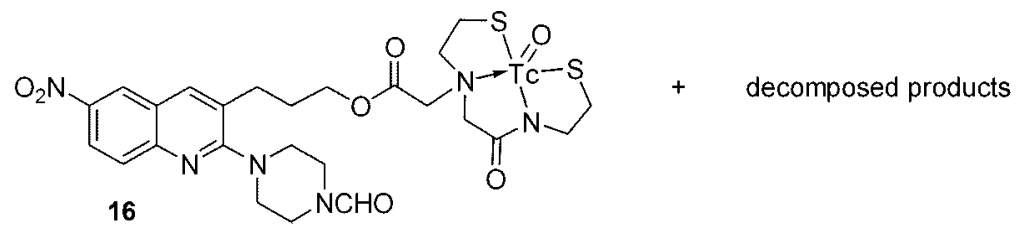

Scheme 4. Incorporation of ${ }^{90,10} \mathrm{Tc}$ onto the ligand 15.

complex at the ester linkage during the incorporation of technetium (Scheme 4).

Due to the instability of the ester linkage, we decided to connect the $\mathrm{N}_{2} \mathrm{~S}_{2}$ tetradentate ligand ditectly with the 6nitroquipazine group wia a reductive amination pathway. $\mathrm{At}$ this point. we changed the protecting group of the piperazine from formyl to the more stable Boc-group. With the same steps used for the alcohol 10, we prepared the alcohol 19 bearing Boc protecting group in a comparable overall yield (Scheme 5).

Oxidation of the alcohol 19 did not proceed as smoothly as we expected, but still provided suflicient amount of the aldehyde 20 with PDC in $41 \%$ yield. Reductive amination of the aldehyde 20 was successfully carried out to give rise to the cortesponding precursor 21 in $80 \%$ yield (Scheme 6).

Removal of the trityl groups with $\mathrm{I}^{-2}$ provided 22 in 
<smiles>CC(=O)OCCCc1cc2cc([N+](=O)[O-])ccc2nc1Cl</smiles>
7

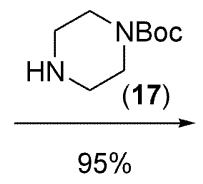

$95 \%$<smiles>CC(=O)OCCCc1cc2cc([N+](=O)[O-])ccc2nc1N1CCN(C(C)(C)C)CC1</smiles><smiles>O=C(O)CCCC(=O)O</smiles>

Scheme 5. Preparation of the Boc-protected 6-nitrocpuipayine derivative.<smiles>[X]CCc1cc2cc([N+](=O)[O-])ccc2nc1N1CCN(C(C)(C)C)CC1</smiles>

$19: \mathrm{X}=-\mathrm{CH}_{2} \mathrm{OH}$

20: $\mathrm{X}=-\mathrm{CHO}(41 \%) \multimap \mathrm{PDC}$
12
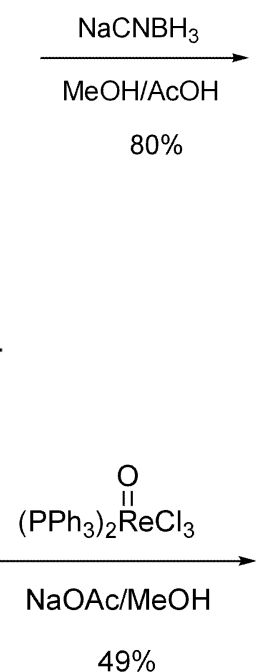

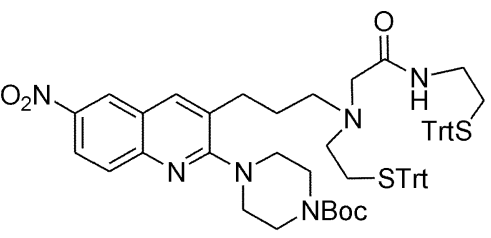

21

Scheme 6. Oxidation and reductive amination of the alcohol 19.<smiles>[X]CCN(CCCc1cc2cc([N+](=O)[O-])ccc2nc1N1CCN([Z1])CC1)CC(=O)NCC[SiH3]</smiles>

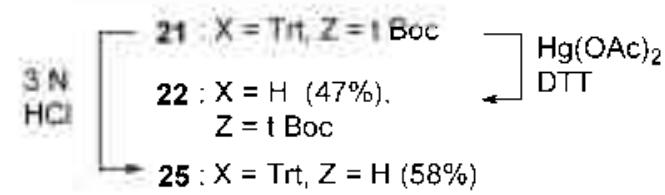<smiles>[Z12]N1CCN(c2nc3ccc([N+](=O)[O-])cc3cc2CCCN2CC(=O)N3CCSP23=O)CC1</smiles>

$23: Z=-\mathrm{tBoc}$ $\left.\begin{array}{l}23: Z=-\mathrm{tBoc} \\ \mathbf{2 4}: Z=-\mathrm{H}(72 \%)\end{array}\right] \begin{gathered}3 \mathrm{~N} \mathrm{HCl} \\ \text { EtOAc }\end{gathered}$

Scheme 7. Ieprolection and formation of the Re-complex 23.24 and 25.

moderate yield, which was subsequently treated with trichlorooxobis(triphenylphosphine)rhenium ${ }^{\text {l] }}$ to furnish the desired Re-complex 23 in $49 \%$ yicld. We also prepared the Boc-deprotected Re-complex 24, upon treatment of the complex 23 with $3 \mathrm{~N} \mathrm{HCl}$ in EtOAc. The Boc-deprotected "Th-complex, however, cannot be prepared with the same sequence used for the Re-complex 24 , for its short half-life $\left(t_{1: 2}-6 \mathrm{~h}\right)$. Thus, the Boc group on 21 was removed with $3 \mathrm{~N}$ $\mathrm{HCl}$ to the ligand system 25, prior to Tc loading step (Scheme 7).

In summary, we have prepared two 6-nitroquipazine based Re-complexes for in vimo binding study against SERT and spectroscopic characterizations plus one ${ }^{(*)}$ Tc-complex for in wo SPECT imaging of SERT. Syntheses of "Tcversion of 23 and 24 as well as their in wine and in vino study are under progress and will be reported near future.

\section{Experimental Section}

General methods. All ${ }^{1}$ I $~ N M R$ spectra were recorded on a $400 \mathrm{Ml} \mathrm{l} z$ Varian NMR spectrometer operating at $400 \mathrm{MI} / 2$ for ']l. Flash column chromatography was performed with Kieselgel 60 At 9385 (230-400 mesh). All solvents used were purified according to standard procedures.

3-|2-(4-Formylpiperazin-1-y])-6-nitroquinoline-3-yl]propyl $\alpha$-Bromoacetate (14). To a solution of $10(20 \mathrm{mg} .0 .058$ $\mathrm{mmol}$ ) in $1.5 \mathrm{~mL}$ of anhydrous $\mathrm{Cl}_{2} \mathrm{Cl}_{2}$ was dropwise added $\mathrm{Et}_{3} \mathrm{~N}(8.9 \mu \mathrm{L}, 0.064 \mathrm{mmol})$ at $-20{ }^{\circ} \mathrm{C}$. To the mixlure was added bromoacelyl bromide $(5.6 \mu \mathrm{L}, 0.064 \mathrm{mmol})$ dropwise at $-20^{\circ} \mathrm{C}$. $\Lambda$ lier $15 \mathrm{~min}$ at $-20^{\circ} \mathrm{C}$. the reaction mixture was warm $10 \mathrm{rl}$ and stirred for $9 \mathrm{~h}$, which was then quenched by the addition of water. The mixture was extracted with $10 \mathrm{~mL}$ of $\mathrm{Cl}_{2} \mathrm{Cl}_{2}$ lhree times. The combined organic layer was dried over $\mathrm{Na}_{2} \mathrm{SO}_{4}$ and concentrated. The product was isolated by flash column chromalography with $\mathrm{EtO} \wedge \mathrm{c} /$ hexanes $(2: 1)$ to give $14(18.7 \mathrm{mg})$ as a yellow solid in $69 \%$ yicld: ']l NMR (400 $\left.\mathrm{MH}_{2}, \mathrm{CDCl}_{3}\right) \delta 8.62(\mathrm{~d}, J-2.8 \mathrm{l} / \mathrm{L}$, I] $) .8 .34(\mathrm{dd}, J-9.2,2.4$ ][z, I] $[$ ). 8.13 (s, I] $) .8 .00$ (s, I] $) .7 .89(\mathrm{~d}, J-9.2][\mathrm{z}, 1 \mathrm{H}), 4.26(\mathrm{t}, J-6.0 \mathrm{]}[\mathrm{z}, 2] \mathrm{l}) .3 .8 \mathrm{l}$ $(\mathrm{s}, 2 \mathrm{l}), 3.78-3.76(\mathrm{~m}, 2] \mathrm{l}), 3.62-3.60(\mathrm{~m}, 2 \mathrm{H}), 3.46-3.43(\mathrm{~m}$,

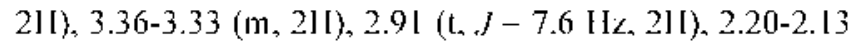
$(\mathrm{m}, 2][) ;{ }^{13} \mathrm{C}$ NMR $\left(100 \mathrm{MH} \mathrm{H}_{2}, \mathrm{CDCl}_{3}\right) \delta 167.0,162.4,160.8$, I48.3, 144.0, I38.2, I35.0, 130.0, I28.7, I24.2, I23.4, $122.6,65.3,50.5,50.0,45.5,40.0,25.6$ : FT-IR $(\mathrm{CHCl})$ $2924.5,2854.4,1738.0,1670.8 \mathrm{~cm}^{-1}$ : IIRMS (FAB) $\mathrm{m} / \mathrm{t}$ $(\mathrm{M}+1)^{-}$calcd for $\mathrm{C}_{10} \mathrm{I}_{22} \mathrm{BrN}_{4} \mathrm{O}_{5} 465.0774$, lound 465.0785 . 
3-[2-(4-Formylpiperavin-1-y])-6-nitmoquinoline-3-y]]prop)yl $N$-(2-tritylsulfanỵl-ethyl)-[(2-tritylsufany lethy]cabamoyl)methyll- $\alpha$-am inoacetate (15). To a solution of 14 (18.7 $\mathrm{mg}$. $0.04 \mathrm{mmol})$ in $1.5 \mathrm{~mL}$ of $\mathrm{CH}_{3} \mathrm{CN}$ was added $12(5.5 .9 \mathrm{mg}$. $0.08 \mathrm{mmol})$ and $\mathrm{K}_{2} \mathrm{CO}_{3}(8.5 \mathrm{mg} .0 .08 \mathrm{mmol})$ at it. After 24 h. the reaction mixture was quenched with water and extracted with $10 \mathrm{~mL}$ of $\mathrm{CH}_{2} \mathrm{Cl}_{2}$ three times. The organic layer was dried over $\mathrm{Na}_{2} \mathrm{SO}_{4}$ and concentrated. The product 15 (16 mg. $37 \%$ ) was obtained by flash column cliromatography with EtOAc/ $/ \mathrm{CH}_{2} \mathrm{Cl}_{2}(2: 1)$ as a yellow solid in $37 \%$ yield: ${ }^{1} \mathrm{H}$ NMR (400 MHz. CDCl $) \delta 8.56$ (d. $J=2.4 \mathrm{~Hz}, \mathrm{lH}) .8 .32$ (dd, $J=9.2 .2 .8 \mathrm{~Hz}, \mathrm{lH}) .8 .09$ (s, lH). $7.9 \mathrm{l}$ (s. lH). 7.87 (d. $J=9.2 \mathrm{~Hz}, \mathrm{lH}), 7.50(\mathrm{t}, J=5.6 \mathrm{~Hz}, \mathrm{lH}), 7.377 .12(\mathrm{ml}, 30$ H). 4.10 (t. $J=6.4 \mathrm{~Hz} .2 \mathrm{H}$ ), 3.73 (dd. $J=5.2,4.8 \mathrm{~Hz}, 2 \mathrm{H}$ ). 3.54 (dd. $J=7.2 .4 .4 \mathrm{~Hz}, 2 \mathrm{H}), 3.40$ (dd, $J=5.2 .3 .2 \mathrm{~Hz}, 2 \mathrm{H}$ ), $3.3 \mathrm{l}$ (dd. $J=4.8 .4 .4 \mathrm{~Hz} .2 \mathrm{H}$ ). 3.23 (s. $2 \mathrm{H}$ ). 3.07 (s. $2 \mathrm{H}$ ). 3.04 (dd. $J=12.4 .6 .4 \mathrm{~Hz}, 2 \mathrm{H}$ ). 2.79 (dd. $J=8.4 .7 .6 \mathrm{~Hz}$. 2H). $2.58(\mathrm{t} . J=6.8 \mathrm{~Hz} .2 \mathrm{H}), 2.36(\mathrm{t} . J=6 .+\mathrm{Hz}, 2 \mathrm{H}) .2 .27(\mathrm{t}$. $J=6.4 \mathrm{~Hz}, 2 \mathrm{H}), 2.09-2.02$ (II. $2 \mathrm{H}):{ }^{1.3} \mathrm{C} \mathrm{NMR}(100 \mathrm{MHz}$. $\left.\mathrm{CDCl}_{3}\right) \delta 171.0 .170 .8,163.0 .161 .3 .148 .9,1+5.16,145.07$. $144.5,138.7,130.5,130.04 .130 .00 .129 .3 .128 .45,128.41$, 127.27. 127.19. 124.8. 124.1, 123.2:67.5, 67.t. 64.7, 58.8, $55.6 .54 .5 .51 .1 .50 .5,46.1,40.6,38.8,32.8,31.1,29.4,28.8$, FT-[R $\left(\mathrm{CHCl}_{3}\right) 3343.4 .3057 .9 .3008 .5 .2960 .0 .2925 .6 .2855 .5$. 1738.9. 1673.1. 1617.2 $\mathrm{cm}^{-1}$ : HRMS (FAB) $\mathrm{ml} / \mathrm{z}(\mathrm{M}+\mathrm{Na})^{\prime}$ calcd for $\mathrm{C}_{62} \mathrm{H}_{62} \mathrm{~N}_{6} \mathrm{NaO}_{6} \mathrm{~S}_{2} 1085.4070$. found 1085.4063.

The 6-nitroquiparine based ${ }^{9 m}$ Tc-complex 16 . To a mixture of the ligand $15(23 \mu \mathrm{g}) . \mathrm{SnCl}_{2}(125 \mu \mathrm{g})$ and $\mathrm{l} \mathrm{mg}$ of tartaric acid in $0.05 \mathrm{~N} \mathrm{HCl}(10 \mathrm{~mL})$ was added sodium perteclunetate $(370-740 \mathrm{MBq})$ at rt. Upon sonication for $\mathrm{l}$ min in water bath. the reaction mixture was heated to $100^{\circ} \mathrm{C}$ for $\mathrm{l} h$. before cooled to $\mathrm{rt}$. The product mixture was antlysed and purified by reversed phase HPLC using gradient system of $\mathrm{H}_{2} \mathrm{O}$ and acetonitrile with flow rate of $1 \mathrm{~mL} / \mathrm{min}$. The peak with retention time of 16 min showed correct UV profile and radioactivity:

3-(3-Acetoxypropyl)-6-nitro-2-(4- $N$-Boc-piperavin-1-yl)quinoline (18). The mixture of $7(217 \mathrm{mg}, 0.69 \mathrm{mmol})$ and Boc protected piperazine $(17,19+\mathrm{mg} .1 .04 \mathrm{mmol})$ in $+\mathrm{mL}$ of anhydrous DMF was stirred for $36 \mathrm{~h}$ at $100^{\circ} \mathrm{C}$ and then cooled to rt. poured into $50 \mathrm{~mL}$ of ice-crushed water. The resulting precipitate was filtered. washed with $50 \mathrm{~mL}$ of water and dried under suction for $10 \mathrm{~min}$. The solid was dissolved in $50 \mathrm{~mL}$ of $\mathrm{CH}_{2} \mathrm{Cl}_{2}$, dried over $\mathrm{Mg}_{2} \mathrm{SO}_{4}$. concentrated and purified by column chromatography with EtOAc/ hexanes ( $1: 3$ ) to give $18(236 \mathrm{mg}$ ) as a yellow solid in $74 \%$ yield: ${ }^{1} \mathrm{H}$ NMR ( $\left.400 \mathrm{MHz} . \mathrm{CDCl}_{3}\right) \delta 8.59$ (d. $J=2.8 \mathrm{~Hz}$. lH). 8.31 (dd. $J=9.2 .2 .4 \mathrm{~Hz} . \mathrm{IH}) .7 .96(\mathrm{~s}, \mathrm{IH}) .7 .85$ (d. $J=$ $9.2 \mathrm{~Hz} .1 \mathrm{H}),+.1+(\mathrm{t}, J=6.4 \mathrm{~Hz} .2 \mathrm{H}), 3.65-3.62(\mathrm{~m} .+\mathrm{H})$, $3.37-3.3+(\mathrm{m} .4 \mathrm{H}), 2.86$ (dd. $J=8.0 .7 .6 \mathrm{~Hz}, 2 \mathrm{H}) .2 .13-2.04$ (m. 2H). $2.06(\mathrm{~s}, 3 \mathrm{H}), 1.50(\mathrm{~s} .9 \mathrm{H}),{ }^{17} \mathrm{C}$ NMR $(100 \mathrm{MHz}$. $\left.\mathrm{CDCl}_{3}\right) \delta 171.4 .163 .4 .155 .3 .149 .1,144.3,138.7,131.0$ $129.2,124.7,124.1,123.1,80.7 .77 .3,64.4 .50 .6,29.5,29.2$, 29.1. 21.7. 21.1: FT-IR $\left(\mathrm{CHCl}_{3}\right)$ 3013.8. 2926.7. 1738.8. 1696.3. $1236.7 \mathrm{~cm}^{-1}$ : HRMS (FAB) $\mathrm{m} / \mathrm{z}(\mathrm{M}+1)^{\prime}$ calcd for $\mathrm{C}_{23} \mathrm{H}_{31} \mathrm{~N}_{4} \mathrm{O}_{6}+59.22+4$. found 459.2245

3-(3-Hydroxypropyl)-6-nitro-2-(4-N-Boc-piperayin-1-yl)- quinoline (19). The mixture of 18 (236 mg. $0.51 \mathrm{mmol}$ ) and $\mathrm{K}_{2} \mathrm{CO}_{3}$ (162 $\mathrm{mg} .1 .53 \mathrm{mmnol}$ ) in $5 \mathrm{~mL}$ of $\mathrm{MeOH}$ and $5 \mathrm{~mL}$ of $\mathrm{CH}_{2} \mathrm{Cl}_{2}$ was stirred for $15 \mathrm{~h}$ at $\mathrm{rt}$. The reaction was quenched by adding $60 \mathrm{~mL}$ of water and the resulting solution was extracted with $20 \mathrm{~mL}$ of $\mathrm{CH}_{2} \mathrm{Cl}_{2}$ three times. The organic layer was dried over $\mathrm{Na}_{2} \mathrm{SO}_{1}$ and concentrated. The alcohol 19 ( $180 \mathrm{mg}$ ) was obtained by column cluromatography with EtOAc/hexanes $(2: 1)$ as a yellow solid in $84 \%$ yield: ' $\mathrm{H}$ NMR $\left(400 \mathrm{MHz} . \mathrm{CDCl}_{3}\right) \delta 8.60$ (d. $\left.J=2.4 \mathrm{~Hz}, \mathrm{iH}\right) .8 .32$ (dd, $f=9.2,2.4 \mathrm{~Hz}, \mathrm{lH}), 7.98(\mathrm{~s}, 1 \mathrm{H}), 7.87(\mathrm{~d}, f=9.2 \mathrm{~Hz}$. lH). $3.65-3.63$ (m. 6H). $3.36-3.34(\mathrm{ml}, 4 \mathrm{H}), 2.9 \mathrm{l}$ (t. $J=7.6$ Hz. 2H), 2.02-1.95 (m, 2H), 1.92 (bt. $1 \mathrm{H}), 1.49$ (s. 9H): ${ }^{1.3} \mathrm{C}$ NMR (100 MHz, $\left.\mathrm{CDCl}_{5}\right) \delta 163.6,155.3,149.0 .144 .3$. $138.9,131.7,129.2,124.9 .124 .0 .122 .9 .80 .7 .77 .4 .62 .2$, 50.7. 33.6, 30.4, 29.2, 28.4; FT-IR $\left(\mathrm{CHCl}_{3}\right) 3440.7 .2925 .8$, 2856.8. $1694.2 \mathrm{~cm}^{-1}$ : HRMS (FAB) $\mathrm{m} / \mathrm{z}(\mathrm{M}+\mathrm{l})^{\prime}$ calcd for $\mathrm{C}_{21} \mathrm{H}_{29} \mathrm{~N}_{1} \mathrm{O}_{5}+17.2138$, found +17.2145 .

3-(3-Oxapropyl)-6-nitro-2-(4-N-Boc-piperavin-1-yl)quinoline (20). The mixture of 19 (180 $\mathrm{mg}, 0.43 \mathrm{mmol})$ and pyridinium dichromate (485 mg. $1.29 \mathrm{mmol}$ ) in $7 \mathrm{~mL}$ of $\mathrm{CH}_{2} \mathrm{Cl}_{2}$ was stirred for $24 \mathrm{~h}$ at $\mathrm{rt}$. The reaction mixture was then filtered through a pad of Celite with $\mathrm{CH}_{2} \mathrm{Cl}_{2}$ and concentrated. The product 20 ( $8+\mathrm{mg}$ ) was obtained by flash column chromatography with EtOAc/hexanes $(1: 2)$ as a yellow solid in $47 \%$ yield: ${ }^{1} \mathrm{H}$ NMR $\left(400 \mathrm{MHz}, \mathrm{CDCl}_{3}\right) \delta$ 9.86 (s. lH). 8.58 (d. $j=2.8 \mathrm{~Hz} .1 \mathrm{H}), 8.31$ (dd, $J=9.2 .2 .4$ Hz. lH). 7.92 (s. IH). $7.86(\mathrm{~d} . J=9.2 \mathrm{~Hz} . \mathrm{lH}), 3.64-3.62(\mathrm{~m}$, +H). $3.36-3.3+(\mathrm{m},+\mathrm{H}), 3.13(\mathrm{t}, J=7.6 \mathrm{~Hz}, \mathrm{lH}) .2 .95(\mathrm{t} . J=$ $7.6 \mathrm{~Hz} .2 \mathrm{H}$ ). 1.50 (s. 9H); ${ }^{1.3} \mathrm{C} \mathrm{NMR}\left(100 \mathrm{MHz}, \mathrm{CDCl}_{3}\right) \delta$ $200.6,163.3,155.3 .149 .2,144.5 .138 .8,130.3 .129 .3,124.7$. $124.1,123.3,80.7,77.3,50.7,44.1,29.2,24.9: \mathrm{FT}-\mathrm{IR}\left(\mathrm{CHCl}_{3}\right)$ 2975.7. 2927.6, 2853.3.1695.8. 1616.2 $\mathrm{cm}^{-1}:$ HRMS (FAB) $\mathrm{m} / \mathrm{z}(\mathrm{M}+\mathrm{l})$ calcd for $\mathrm{C}_{21} \mathrm{H}_{2}=\mathrm{N}_{1} \mathrm{O}_{5}+15.1981$. found 415.1965 .

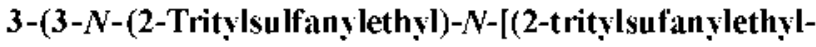
cabamoyl)methyl]am ino-propyl)-6-nitro-2-(4-N-Boc-piperayin-1-yl)quinoline (21). To a solution of $\mathbf{2 0}(8+\mathrm{mg} .0 .20$ mmol) in $4 \mathrm{~mL}$ of $\mathrm{MeOH} /$ acetic acid (99: 1) was added 12 (209 $\mathrm{mg}, 0.30 \mathrm{mmol}$ ) and sodium cyanoborohydride $(19 \mathrm{mg}$. $0.30 \mathrm{mmol}$ ) at $\mathrm{rt}$. After stirring for $5 \mathrm{~h}$ at $\mathrm{rt}$. reaction mixture was quenched by adding $10 \mathrm{~mL}$ of water. The resulting solution was extracted with $15 \mathrm{~mL}$ of $\mathrm{CH}_{2} \mathrm{Cl}_{2}$ three times. The organic layer was dried over $\mathrm{Na}_{-} \mathrm{SO}_{4}$ and concentrated. The product 21 (153 mg) was obtained by flash columu chromatography with EtOAchexanes $(1: 2)$ as a yellow solid in $71 \%$ yield: 'H NMR ( $\left.400 \mathrm{MHz}, \mathrm{CDCl}_{3}\right) \delta 8.39(\mathrm{~d}, d$ $=2.4 \mathrm{~Hz}, \mathrm{IH}) .8 .3 \mathrm{I}(\mathrm{dd}, J=9.2 .2 .8 \mathrm{~Hz} . \mathrm{IH}) .7 .83(\mathrm{~d}, J=9.2$ Hz. lH). 7.79 (s. lH). $7.51(\mathrm{t} . J=6.0 \mathrm{~Hz}, \mathrm{lH}) .7 .38-7.09(\mathrm{~m}$. $30 \mathrm{H}) .3 .57-3.56(\mathrm{~m}, 4 \mathrm{H}), 3.29-3.26(\mathrm{~m}, \mathrm{H}), 3.04(\mathrm{dd} J=$ 12.t. $6.0 \mathrm{~Hz}, 2 \mathrm{H}), 2.90$ (s. $2 \mathrm{H}$ ). 2.71 (t. $J=7.6 \mathrm{~Hz}, 2 \mathrm{H}$ ). $2.45-2.35(\mathrm{~m}, 6 \mathrm{H}), 2.28(\mathrm{t}, J=6.0 \mathrm{~Hz} .2 \mathrm{H}) .1 .86-1.78(\mathrm{~m}$. 2H). 1.49 (s. 9H): ${ }^{1.5} \mathrm{C} \mathrm{NMR}\left(100 \mathrm{MHz}, \mathrm{CDCl}_{3}\right) \delta 171.3$. $163.4,155.3,149.0 .145 .2,1+5.1 .144 .3,138.5,131.2,130.1$. $130.0,129.1,128.5 .128 .4,127.4 .127 .3,127.1 .124 .7,124.2$. $123.1,80.1,67.6,67.5,59.1,55.4,54.7,50.5,38.8,33.0$. 31.0. 30.1, 29.3. 28.2: FT-IR $\left(\mathrm{CHCl}_{3}\right) 3348.3 .3058 .4$. 2973.6. 2928.4. 2856.2. $1682.7 \mathrm{~cm}^{-1}$ : HRMS (FAB) $\mathrm{ml} / \mathrm{z}$ $(\mathrm{M}+\mathrm{Na})^{\circ}$ calcd for $\mathrm{C}_{6 i} \mathrm{H}_{6 \times} \mathrm{NaN}_{6} \mathrm{O}_{3} \mathrm{~S}_{2} \quad 1099.4590$. found 
1099.4562

3-(3- $N$-(2-Mercaptoethy $])-N$-[(2-mercaptoethylcabamoy)methyllaminopropyl)-6-nitro-2-(4- $N$-Boc-piperavin-1y)quinoline (22). To a stirred solution of 21 ( $153 \mathrm{mg}, 0.14$ mumol) in a $1: 1$ mixture of EtOAc and EtOH (7 mL) was added a solution of mercury (II) acetate (115 mg. 0.36 munol) in EtOH (3 $\mathrm{mL})$. The reaction mixture was stirred for 20 min at $80^{\circ} \mathrm{C}$ and then cooled to it. The reaction mixture was treated with dithiothreitol $(65 \mathrm{mg} .0 .+2 \mathrm{mumol})$, stirred for an additional $10 \mathrm{~min}$ before passed through a pad of Celite with EtOAc. The filtrate solution was concentrated and purified by columm cluromatography with $\mathrm{MeOH} / \mathrm{CH}_{2} \mathrm{Cl}_{2}$ (l : 100) to furnish $22(46 \mathrm{mg})$ as a yellow solid in $56 \%$ yield: ' H NMR (400 MHz. CDCl $) \delta 8.59$ (d, $J=2.4, \mathrm{lH}$ ), 8.31 (dd. $J=8.8,2.4 \mathrm{~Hz}, \mathrm{lH}$ ). 7.97 (s. $\mathrm{lH}$ ). 7.86 (d. $J=8.8$ Hz. lH). 7.77 (t. $J=6.0 \mathrm{~Hz}, \mathrm{lH}) .3 .63-3.6 \mathrm{l}(\mathrm{ml} . \mathrm{H}) .3 .+7$ $($ dd. $J=12.4 .6 .0 \mathrm{~Hz} .2 \mathrm{H}), 3.36-3.3+(\mathrm{ml} .+\mathrm{H}), 3.1+(\mathrm{s}, 2 \mathrm{H})$. 2.81 (t. $J=7.2 \mathrm{~Hz} .2 \mathrm{H}$ ). $2.75-2.57$ (m. loH). 1.99-1.91 (m. 2H). $1.49(5,9 \mathrm{H}) ;{ }^{13} \mathrm{C}$ NMR (100 $\left.\mathrm{MHz} . \mathrm{CDCl}_{3}\right) \delta 171.5$. 163.4, 155.3. 149.1, 144.4. 138.4. 131.0, 129.2. 124.7, 124.1. $123.1,80.8,59.3,58.4,55.2,50.6,42.6,30.5,30.1,29.2$. 28.0. 25.5. 23.7; FT-IR ( $\left.\mathrm{CHCl}_{3}\right) 3343.2,2974.0 .2929 .4$. $2856.0 .1681 .8 \mathrm{~cm}^{-1}$ : HRMS (FAB) $\mathrm{m} / \mathrm{z}(\mathrm{M}+\mathrm{Na})$ calcd for $\mathrm{C}_{2} \mathrm{H}_{11} \mathrm{NaN}_{6} \mathrm{O}_{5} \mathrm{~S}_{2} 615.2399$, found 615.2396.

Re-complex 23. To a stirred solution of 22 ( $+6.7 \mathrm{mg}$. $0.079 \mathrm{mmol})$ in $\mathrm{MeOH}(13 \mathrm{~mL})$ were added $1 \mathrm{M} \mathrm{NaOAc}$ in $\mathrm{MeOH}$ ( $1.2 \mathrm{~mL} .1 .185 \mathrm{mumol}$ ) and trichlorooxo-bis(triphenylphosphine)rhenium (79 $\mathrm{mg} .0 .095 \mathrm{mmol}$ ) at rt. The reaction mixture was heated to $80^{\circ} \mathrm{C}$ and stirred for $2 \mathrm{~h}$. The cooled reaction mixture was diluted with EtOAc $(30 \mathrm{~mL})$, washed with water dried over $\mathrm{Na}_{2} \mathrm{SO}_{4}$ and concentrated. The Recomplex 23 ( $42.5 \mathrm{mg}$ ) was obtained by flash column cluromatography with $\mathrm{MeOH} / \mathrm{CH}_{2} \mathrm{Cl}_{2}(\mathrm{l}: 60)$ as yellow solids in $68 \%$ yield: 'H NMR (400 MHz, $\left.\mathrm{CDCl}_{3}\right) \delta 8.62$ (d. $J$ $=2 .+\mathrm{Hz}, 1 \mathrm{H}), 8.3+(\mathrm{dd}, J=9.2 .2 .4 \mathrm{~Hz}, 1 \mathrm{H}) .8 .02(\mathrm{~s}, 1 \mathrm{H})$. $7.90(\mathrm{~d}, J=9.2 \mathrm{~Hz} .1 \mathrm{H}) .4 .60(\mathrm{~d}, J=16.8 \mathrm{~Hz}, \mathrm{lH}) .4 .55$ (d. $J$ $=6.4,5.2 \mathrm{~Hz}, 1 \mathrm{H}),+.10(\mathrm{~d} . J=16.8 \mathrm{~Hz}, \mathrm{lH}), 4.10-4.06(\mathrm{~m}$. overlapped. $\mathrm{lH}$ ). 3.96 (ddd. $J=17.6,14.8 .8 .+\mathrm{Hz}, \mathrm{lH}$ ). 3.63-3.57 (m. 4H) 3.34-3.31 (m. 4H), 3.33-3.31 (m. $+\mathrm{H})$, $3.28-3.23$ (m. 2H) $3.21-3.13$ (m. 2H), 2.9l-2.84 (m. $3 \mathrm{H}$ ), 2.33-2.22 (m, 2H). 1.70-1.62 (m, 2H). 1.50 (s. 9H): ${ }^{1.3} \mathrm{C}$ NMR (100 MHz, $\left.\mathrm{CDCl}_{3}\right) \delta 187.2 .163 .3 .155 .3 .149 .3$. $144.6,138.8,129.7,129.6 .124 .7 .124 .1 .123 .6 .80 .9 .67 .5$. $65.4 .63 .7,60.6,50.9 .48 .8 .39 .8,30.5,29.6 .29 .3 .25 .3$. FTIR $\left(\mathrm{CHCl}_{3}\right) 2928.0,2856.7 .1681 .2,1651.2 .965 .8 \mathrm{~cm}^{-1}$; HRMS (FAB) $\mathrm{m} / \mathrm{z}(\mathrm{M}+\mathrm{Na})^{\prime}$ calcd for $\mathrm{C}_{2}-\mathrm{H}_{3}: \mathrm{NaN}_{6} \mathrm{O}_{4} \mathrm{ReS}_{2}$ 815.1671. found 815.1703 .

Re-complex 24. To a solution of 23 (32 $\mathrm{mg}, 0.040 \mathrm{mmol})$ in $3 \mathrm{~mL}$ of EtOAc was added $3 \mathrm{~N} \mathrm{HCl}(1.5 \mathrm{~mL})$ at $\mathrm{rt}$. After stirring for $24 \mathrm{~h}$ at $\mathrm{rt}$. the reaction mixture was diluted with EtOAc $(10 \mathrm{~mL})$. washed with $1 \mathrm{M} \mathrm{NaHCO}_{3}(2 \times 10 \mathrm{~mL})$ and water $(10 \mathrm{~mL})$. The organic layer was dried over $\mathrm{Na}_{2} \mathrm{SO}_{4}$. concentrated and purified by column chromatography with $\mathrm{MeOH} / \mathrm{CH}_{2} \mathrm{Cl}_{2}(1: 10)$ to fumish $24(20 \mathrm{mg})$ as a yellow: solid in $72 \%$ yield: 'H NMR (400 MHz, $\mathrm{CDCl}_{3}$ ) $\delta 7.99$ (s, 1H). $7.90(\mathrm{~d}, J=9.2 \mathrm{~Hz}, \mathrm{IH}) .+6 \mathrm{l}(\mathrm{d} . J=16.0 \mathrm{~Hz}, \mathrm{IH}) .4 .56$ (d. $J=6.4 .5 .2 \mathrm{~Hz} .1 \mathrm{H})+.11(\mathrm{~d}, J=16.0 \mathrm{~Hz} .1 \mathrm{H}), 4.10-4.06$ (m. overlapped, lH). $4.01-3.9+$ (n. lH). 3.65-3.58 (m. lH), 3.36-3.33 (m, +H) , 3.30-3.14 (m, +H), 3.10-3.08 (m. 4H), 2.94-2.84 (m, 3H). 2.34-2.24 (m, 2H). 1.70-1.62 (m, 2H); ${ }^{1.2} \mathrm{C}$ NMR (100 MHz. $\left.\mathrm{CDCl}_{3}\right) \delta 187.2,163.6 .149 .5,144.5$. $138.8,129.7,129.5,124.6 .124 .1 .123 .5 .67 .5 .65 .3 .63 .8$. 60.0. 52.2. 48.8. 46.8. 39.8. 29.9. 25.2; FT-IR $\left(\mathrm{CHCl}_{3}\right) 2924.8$. 2855.7. 165l.1,964.9 $\mathrm{cm}^{-1}$. HRMS (FAB) $\mathrm{m} / \mathrm{z}(\mathrm{M}+\mathrm{l})$ calcd for $\mathrm{C}_{22} \mathrm{H}_{30} \mathrm{~N}_{6} \mathrm{O}_{1} \mathrm{ReS}_{2} 693.1327$. found 693.1325 .

3-(3-N-(2-Tritỵlsulfanỵlethỵl)- $N$-[(2-tritỵlsufanỵ lethỵlcabamoyl)methyl]amino-propyl)-6-nitro-2-(piperayin-1y)quinoline (25). To a solution of 21 (16 $\mathrm{mg}$. (0.015 munol) in $1.5 \mathrm{~mL}$ of EtOAc wad added $3 \mathrm{~N} \mathrm{HCl}(1 \mathrm{~mL})$ at room temperature. After stirring for $2+\mathrm{h}$ at $\mathrm{rt}$. the reaction mixture was diluted with EtOAc $(10 \mathrm{~mL})$. The organic portion was washed with $1 \mathrm{~N} \mathrm{NaHCO}_{3}(2 \times 10 \mathrm{~mL})$ and water $(10 \mathrm{~mL})$. The organic layer was dried over $\mathrm{Na}_{2} \mathrm{SO}_{1}$ and concentrated. The product $25(8.5 \mathrm{mg})$ was obtained by flash column chromatography with $\mathrm{MeOH} / \mathrm{CH}_{2} \mathrm{Cl}_{2}(1: 30)$ as a yellow solid in $58 \%$ yield: ' $\mathrm{H}$ NMR $\left(400 \mathrm{MHz} . \mathrm{CDCl}_{3}\right) \delta 8.36(\mathrm{~d}, f$ $=2.4 \mathrm{~Hz}, \mathrm{lH}) .8 .28(\mathrm{dd}, j=9.2,2.4 \mathrm{~Hz} . \mathrm{IH}) .7 .8+(\mathrm{d}, j=9.2$ Hz. lH) .7 .76 (s. lH) $.7 .52($ t. $J=6.0 \mathrm{~Hz}, \mathrm{lH}) .7 .35-7.07(\mathrm{~m}$. $30 \mathrm{H}), 3.31-3.28(\mathrm{~m}, 4 \mathrm{H}), 3.0+(\mathrm{dd} . J=12.0,6.4 \mathrm{~Hz}, 2 \mathrm{H})$, $3.00-2.96$ (m. $4 \mathrm{H}), 2.9 \mathrm{I}$ (s. 2H). 2.72-2.68 (m. 2H). 2.45$2.35(\mathrm{~m}, 6 \mathrm{H}) .2 .28$ (t. $J=6.0 \mathrm{~Hz} .2 \mathrm{H}), 1.84-1.76(\mathrm{~m} .2 \mathrm{H})$ : ${ }^{1.3} \mathrm{C}$ NMR (100 $\left.\mathrm{MHz} . \mathrm{CDCl}_{3}\right) \delta 171.4,163.7 .149 .2,145.2$. $145.1,1+4.0,138.3 .131 .3,130.1 .130 .0,129.0 .128 .5,128.4$. 127.4, 127.3. 124.5, 124.2. 123.0, 67.6, 67.5, 59.1, 55.3, 54.8. 51.9. 46.8. 38.8. 33.0, 31.0, 30.4, 28.1: FT-lR $\left(\mathrm{CHCl}_{3}\right)$ 2917.4. 2853.3. 1671.1. $1615.2 \mathrm{~cm}^{-1}$ : HRMS (FAB) $\mathrm{m} / \mathrm{z}$ $(\mathrm{M}+1)$ calcd for $\mathrm{C}_{61} \mathrm{H}_{61} \mathrm{~N}_{6} \mathrm{O}_{3} \mathrm{~S}_{2} 977.4247$, found 977.4244.

Acknowledgment. This work was supported by Nation Mid \& Long Term Nuclear R\&D Program of the Ministry of Science and Technolog. (MOST) in Korea.

\section{References and Notes}

1. Povlock. S. L.: Amara S. G. In Netrotrofusmitte' Trowsponters; Sthucture Function and Regulation: Reith. M. E. A.. Ed.: Ilumania: Now Jerses: 1997; pr 1-28.

2. Meltzer, C. C.: Smith, G.: Dekoskiy. S. T.: Pollock. B. G.: Mathis, C. A.: Moore. R. Y.: Kupter. J. I.: Resnolds. C. F. Veumpstcophamacology 1998. /8. 407

3. (a) Frazer. A. J. Clin. Psthatry 1997, 6. 9. (b) Wone. D. T.: Bymaster. F. P. . Id: Frp. Ifed Biol 1995. 363. 77. (b) Szabo. Z.: Sclettel, UJ.: Matlews, W. B.: Ratcrt, II. T.: Szabo. K.: Kraut. M.: Palunom, S.: Ricaurte. G. A.: Dannals. R. Г. J. Cereb. Blood Flon Aetab. 1999, 19. 967. (c) Wilson, A. A.: Ginovart, N.; Schnidt. M.: Meyer. I. H.: Threlkeld. I' G.: Houle. S. . . . I $e^{\prime} d .\left(h^{\prime} m .2000\right.$. 43. 3103

4. Suehiro. M.: Schelfel. U.: Ravert. H. T.: Dannals. R. F.: Wạner. II. N., Ir. Life Sci. 1993, $53,883$.

5. Oya, S.: Kung. M.-P.; Acton, P. D.: Mu, M.: Hou. C.: Kung. HI. Г. J. Hed. Chem 1999, +2, 33.3.

6. (a) Hashimolo. K.: Goromant. T. Fit. J. Fhathacol 1990. 180. 272. (b) Hashimoto. K.: Goromanu. T. Vemophamacologe 1991. 30. 113.

7. Volkert, W. A.; Jurisson, S. In Technefium and Rhenim: Their Chemistry and lts Applications: Yoshilara. K.; Omori. T., Fd.: Springer: New York, 199.3; p 12.3

8. (a) Mathis. C. A.: Enas. I. D.: Hanrahan. S. M.: Akgun. E. $J$. 
Iabelled C'ompd Radiopharm. 1994. 34.905. (b) Mathis. C. A.: Tay.lor. S. E.: Biegon. A.: Enas. J. D. Bram Reseanch 1993. 619. 229. (c) Biegon. A.: Ma1his. C. A.: Hanralhan1. S. M.: Jagust. W. T. Brain Restarh 1993.619.236.

9. (a) Jagust. W. J.: Fberling, J. I .: Biegon. $\Lambda$ : Taylor, S. F.: Van Brockin. II. F.: Jordan, S.: Hanrahan, S. M.; Roberts, J. A.; Bremnan. K. M.: Matlis. C. A. J. Azd. Med. 1996. 37. 1207-1214. (b) Lundkvisi. C.: Loc h. C.: Halldin. C.: Marhis. C.: Swaln. C.G.: Merlens. I.: Farde. L.: Maciere. B. J. Labelled compd.
Radiopharm. 1947. 40.586

10. (a) Lee. B. S.: Chu. S.: Chi. D. Y.: Choe. Y. S.: ,eong. K. I.: Jin. C. J. Med Chem 2002. submitted (b) Lee. B. S.: Chu. S.: Lee. B. C:: Chi, D. Y.: Choe, Y. S.: Jeong. K. I. Jin, C. Biong Med. Chem. Leff. 2000. J(J. 1559. (c) I.ee. B. S.: I.ee. B. C.. Jutt. J.-C.: Chi. D. Y. Hettrockel's 1998, 48.263 .37

11. ONeil. J. P:: Wilson. S. R.: Katzenellenbogen. I. A. Ihorg. (hem 1994.33.319. 